\title{
Study of Some Soil Properties and Evaluation of the Level of Contamination with Lead in Baia Mare, Aghires and Copsa-Mica, Romania
}

\author{
MATEI GHEORGHE ${ }^{1}$, GEORGE LIVIU POPESCU³, DOINA PRODAN², ILEANA COJ OCARU1*, MONICA GROZA4 \\ IUniversity Craiova, 13 A. I. Cuza Str., 200585, Craiova, Romania \\ 2Babes Bolyai University - Raluca Ripan Chemistry Research Institute, 30 Fantanele Str., 400294, Cluj-Napoca, Romania \\ ${ }^{3}$ Technical University of Cluj-Napoca, 103-105 Muncii Str., 400641, Cluj-Napoca, Romania \\ ${ }^{4}$ Alvogen, 44B Theodor Pallady Blvd, 032266, Bucharest, Romania
}

The article is focused on soil quality studies of three contaminated areas from Romania, affected by exploitation: northwest of Baia Mare near Romplumb S.A., Aghire- squarry area, and Copsa Mica. The values of $\mathrm{pH}$, the hygroscopic water content were studied along to sieves analysis applied for gradation and size analysis. A semi-quantitative analysis of the content of the soli was made by SEM-EDAX.

Kewords: soil, heavy metals, SEM, $\mathrm{pH}$

A high level of heavy metals such as lead $(\mathrm{Pb})$, zinc $(\mathrm{Zn})$, copper (Cu), arsenic (As), cadmium (Cd) and antimony (Sb) are usually found in mining areas, mineral processing or metal factories, due to automotive traffic emissions or intense agricultural practices [1-5]. Consequently, soil contamination with heavy metals is a worrying global environmental problem, as these elements can be transferred into the hydrosphere and biosphere, thus becoming a danger to human health. Consequently, the mobility and bioavailability of heavy elements in the soil play an important role in the assimilation of these contaminants by plants and animals [11].

It is well known that heavy metal contamination does not directly affect the physical and chemical properties of soil but reduces soil biological activity and decreases the availability of nutrients. It is also a serious threat to human health by introducing into food chains through water and soil.

Contamination of soil with heavy metals is quite serious in some areas of Romania. It is, therefore, necessary to study the status of heavy metal contamination in the soil and to assess their impact on the environment [10]. Most studies on heavy metal contamination begin with the determination of its spatial distribution [4, 12-14].

Generally, pollutant concentrations can show complex spatial patterns with peak values and a large variation in concentrations. Therefore, it is difficult to detect polluted areas over a critical level, even if the data were collected at a large number of observation sites [14].

The Baia Mare (B), Copsa Mica (C) and Aghires areas represent areas of greatinterest for studies on the behavior of heavy elements in contaminated soils. In this respect, we conducted a research focused on the identification of heavy metals (lead) in the soil in the above-mentioned areas.

\section{Experimental part}

The study areas are centered on three contaminated sites in Romania: Baia Mare, Copsa Mica, and Aghires. To analyze the current soil quality, 10 soil samples were taken from the affected area and 2 were taken from outside the area affected by the exploitation as control samples.

Soil samples were taken from the northwest of BaiaMare, where S.C. Romplumb S.A is located (samples B), from Aghireo quarry area - located at the boundary between Cluj and Salaj county (samples P) and Copsa Mica area (samples C). The collection of soil samples was done in plastic bags with a plastic spatula. The depth from which samples were collected was $25-30 \mathrm{~cm}$. To determine the $\mathrm{pH}$, soil samples were processed according to SR ISO 10390/2005 (instrumental specific method for routine $\mathrm{pH}$ determination) using a glass electrode. For this purpose, $50 \mathrm{~g}$ of soil was weighed, to which distilled water was added at a dilution of $1: 5$, under continuously stirring for two hours. Finally, the solution was filtered, and the $\mathrm{pH}$ was measured using an HI 255 Multiparameter Laboratory Analyzer.

Determination of hygroscopic moisture content based on the loss of hygroscopic water is done by drying the soil in an electric oven at $105 \pm 5^{\circ} \mathrm{C}$ for $6-8 \mathrm{~h}$. At this temperature, the decomposition of organic substances can generally be neglected. The weight loss considered hygroscopic water is expressed in percents being calculated with the following relation:

$$
U \%=([(a+b)-(a+b-u)] \times 100) / b=(U \times 100) / b
$$

where: U\% is hygroscopic water content[\%]; a - the weight of the empty ampoule, dried at $105^{\circ} \mathrm{C}$ and brought to constant weight; $(a+b)$ - ampoule weight with air dried soil; $b$ - the weight of dry soil taken for analysis; $(a+b-u)$ - weight of the weighing ampoule plus dried soil at $105^{\circ} \mathrm{C}$; $u$ - the amount of water released from the soil during drying at $105^{\circ} \mathrm{C}$.

Sieves analysis was used for gradation and size analysis after soil drying in an oven. The weight percentages obtained after sieving are used to determine the texture class. The chemical composition of in situ samples was estimated using a scanning electron microscope (SEM Quanta InspectF-FEI) equipped with an energy dispersive system (EDAX).

\section{Results and discussions}

The determination of the $\mathrm{pH}$ of the soil samples

The analyzed samples, except for the two blank (M1 and M2), are very acidic. The blank soil samples are neutral, while the $\mathrm{pH}$ of the collected samples varies between 3.8 and 7.1 (fig.1). 


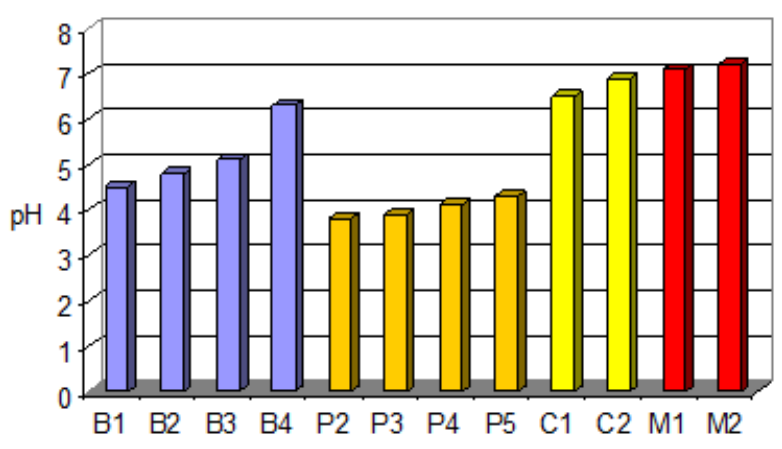

Fig. 1. The values of $p H$ for soils from Baia Mare (samples B1-B4), Aghires (samples P2-P5) and Copsa-Mica (samples C1, C2)

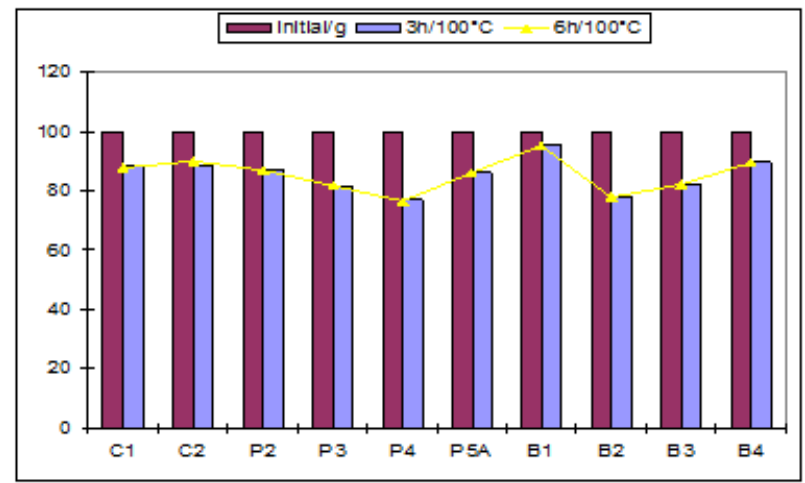

Fig. 2. The values of hygroscopic water content for soils from Baia Mare (samples B1-B4), Aghires (samples P2-P5) and Copsa-Mica (samples $\mathrm{C} 1, \mathrm{C} 2$ )

Based on the data from figure 1 one can conclude that there is an acidic contamination in the analyzed area. The smallest values of $p H$ (from 3.8 to 4.2) were measured for samples $P$ from Aghires quarry. Acidic soils were identified also in Baia Mare (samples B1-B4 with a pH between 4 and 6), while in Copsa-Mica the soil is almost neutral ( $\mathrm{pH}$ range between 6 and 7). Acidic soils contamination favor the increasing of the mobility of heavy metal ions and lead to soil degradation by exceeding the values for heavy metal content up to about $100 \mathrm{~cm}$. Environment pollution in the Baia Mare area has also impacted on the health of the population. Studies on the risk groups for lead, cadmium and arsenic pollution [15-18] have shown concentrations of pollutants in the human body thathave largely exceeded the reference levels, especially for the lead indicator (lead in blood being the main parameter to indicate the concentration of lead in the human body), which explains the increased incidence rates of specific morbidity in the area of respiratory, digestive, renal, endocrine and metabolic disease.

\section{Determination of dry matter and water content - Gravimetric method}

Figure 2 presents the hygroscopic water content of the soil determined under laboratory conditions recorded at 3 and $6 \mathrm{~h}$. One can see the lowest values of hygroscopic water content after $3 \mathrm{~h}$ for $\mathrm{P} 4$ soil from Aghires and B2 soil taken from the Baia Mare area.

In the case of a dynamic soil system, the kinetics of mineral dissolution must be taken into consideration. The small rate of dissolution of lead compared to different minerals leads to a low bioavailability and a minor risk of circulation of lead in the soil and groundwater. Thus, in addition to solubility, the dissolution rate should be considered for assessing the stability of a Pb compound. Lead phosphates have low solubility $(0.000014 \mathrm{~g} / 100 \mathrm{~mL})$, which are of several orders of magnitude less soluble than lead carbonates $(0.00011 \mathrm{~g} / 100 \mathrm{~mL})$ and sulfates $(0.00443$ $\mathrm{g} / 100 \mathrm{~mL}$ ).

However, when solubility is estimated, the most studies are focused on soils that contain quite high concentrations of metal. Assessing the availability traces of metals is a problem not only in terms of contamination but also in situations of shortage in agricultural systems.

\section{Sieves gradation and size analysis}

Figure 3 shows the granulometric plot of soil size distribution in Baia- Mare while figure 4 the granulometric distribution of Copsa-Mica soil.

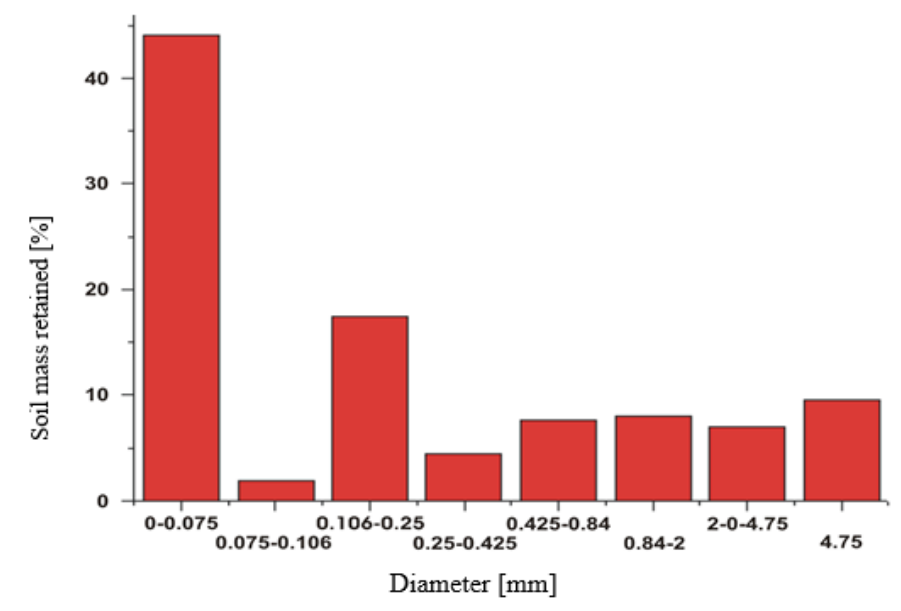

Fig. 3. Granulometric distribution for the soil from Baia Mare

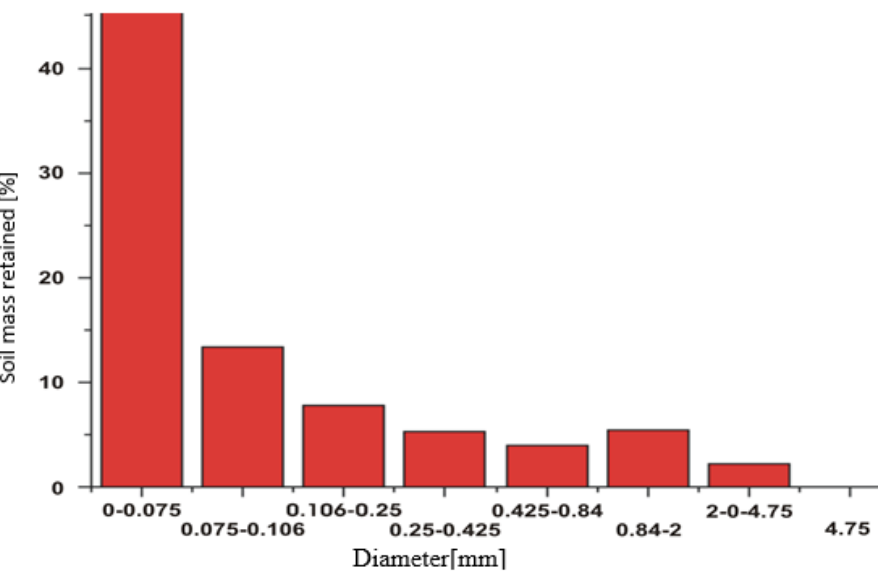

Fig. 4. Granulometric distribution for the soil from Copsa Mica

One can see that in the soil from Baia Mare more than $44 \%$ from grains are smaller than $0.075 \mathrm{~mm}, 12,5 \%$ from soil are from 0.075 to $0.106 \mathrm{~mm}$, while the rest have higher diameters. In the soil from Copoa-Micã, about $47 \%$ from grains are smaller than $0.075 \mathrm{~mm}, 12.7 \%$ grains from soil are from 0.075 to $0.106 \mathrm{~mm}$, while the rest have higher diameters.

\section{Soil analysis by Scanning Electron Microscopy (SEM-EDAX)}

Total concentrations of soil metals traces are not good indicators of their bioavailability. However, information on total solid soil concentrations, together with chemically selected soil properties can be used to estimate the concentration of free metal ions in the soil.

Elemental analysis of toxic elements in samples in large quantities (major elements) or in traces (minor elements) is essential in addressing environmental pollution problems. Also, the analysis of these elements allows the obtaining of information on the formation and origin of different geological formations as well as data that contribute to the clarification of past geological processes [6-9]. 

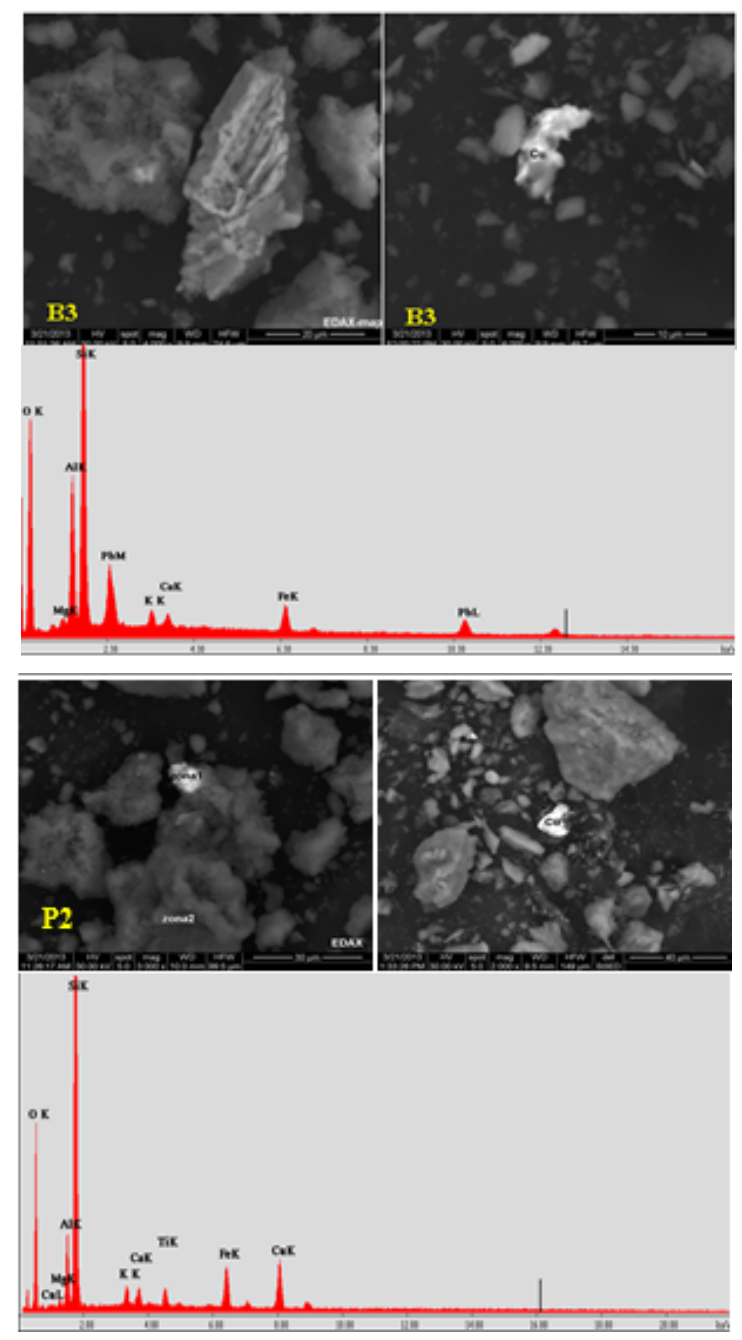

\section{Table 1}

THE PERCENTAGE CONCENTRATIONS OF THE ELEMENTS FROM SOILS FROM BAIA MARE (SAMPLES B2, B3), AGHIRES (SAMPLES P2, P3) AND COPSA-MICA (SAMPLES C1, C2) DETERMINED BY SEM-EDX (\%)

\begin{tabular}{|c|c|c|c|c|c|c|c|c|c|c|c|c|}
\hline \multirow{3}{*}{ Element } & \multicolumn{4}{|c|}{ Aghireș } & \multicolumn{4}{|c|}{ Baia Mare } & \multicolumn{4}{|c|}{ Copșa Mică } \\
\hline & \multicolumn{2}{|c|}{$\mathrm{P} 2$} & \multicolumn{2}{|c|}{ P3 } & \multicolumn{2}{|c|}{ B2 } & \multicolumn{2}{|c|}{ B3 } & \multicolumn{2}{|c|}{$\mathrm{C} 1$} & \multicolumn{2}{|c|}{$\mathrm{C} 2$} \\
\hline & Average & $S D$ & Average & $S D$ & Average & $S D$ & Average & $S D$ & Average & $S D$ & Average & $S D$ \\
\hline 0 & 40.29 & 0.133 & 26.99 & 0.086 & 50.41 & 0.163 & 39.56 & 0.042 & 38.51 & 0.404 & 36.47 & 0.448 \\
\hline $\mathrm{Al}$ & 17.16 & 0.064 & 4.107 & 0.053 & 5.659 & 0.018 & 10.86 & 0.039 & 5.921 & 0.026 & 8.844 & 0.116 \\
\hline $\mathrm{Ca}$ & 3.459 & 0.012 & 4.666 & 0.007 & 15.00 & 0.048 & 0.957 & 0.005 & 6.216 & 0.006 & 6.243 & 0.050 \\
\hline $\mathrm{Cu}$ & 1.994 & 0.010 & 2.098 & 0.003 & 2.940 & 0.047 & 5.667 & 0.096 & 2.987 & 0.025 & 1.500 & 0.039 \\
\hline $\mathrm{Fe}$ & 3.578 & 0.012 & 10.40 & 0.090 & 5.520 & 0.018 & 6.698 & 0.024 & 5.400 & 0.013 & 5.707 & 0.138 \\
\hline $\mathbf{K}$ & 0.439 & 0.003 & 2.330 & 0.035 & 1.385 & 0.047 & 1.622 & 0.007 & 1.834 & 0.008 & 3.758 & 0.125 \\
\hline $\mathrm{Mg}$ & 4.184 & 0.015 & 2.881 & 0.048 & 0.538 & 0.050 & 0.857 & 0.004 & 4.413 & 0.022 & 1.199 & 0.011 \\
\hline $\mathrm{Na}$ & 3.987 & 0.019 & 0.000 & 0.000 & 1.591 & 0.009 & 0.765 & 0.026 & 1.362 & 0.053 & 1.627 & 0.109 \\
\hline $\mathbf{P}$ & 1.127 & 0.005 & 3.868 & 0.004 & 1.949 & 0.012 & 1.295 & 0.006 & 1.961 & 0.027 & 3.480 & 0.075 \\
\hline $\mathrm{Pb}$ & 0.000 & 0.000 & 0.000 & 0.000 & 5.380 & 0.017 & 2.200 & 0.011 & 1.297 & 0.008 & 4.997 & 0.023 \\
\hline $\mathrm{Si}$ & 20.35 & 0.023 & 35.54 & 0.111 & 17.68 & 0.057 & 29.20 & 0.047 & 23.12 & 0.064 & 21.74 & 0.265 \\
\hline $\mathrm{Ti}^{-}$ & 0.170 & 0.001 & 0.959 & 0.052 & 0.913 & 0.066 & 0.509 & 0.003 & 0.644 & 0.067 & 1.659 & 0.008 \\
\hline $\mathrm{Zn}$ & 3.907 & 0.131 & 6.769 & 0.014 & 4.995 & 0.018 & 2.901 & 0.094 & 6.886 & 0.038 & 3.990 & 0.018 \\
\hline
\end{tabular}

Although there are several analytical methods that can be used to analyze environmental samples but only a few are non-destructive and allow for the determination of light elements. The statistical analysis was done after semiquantitative analysis using SEM-EDAX (fig. 5) of soil microelements. The mean and standard deviation of the concentrations of some microelements (heavy metals) in the soil are shown in table 1.
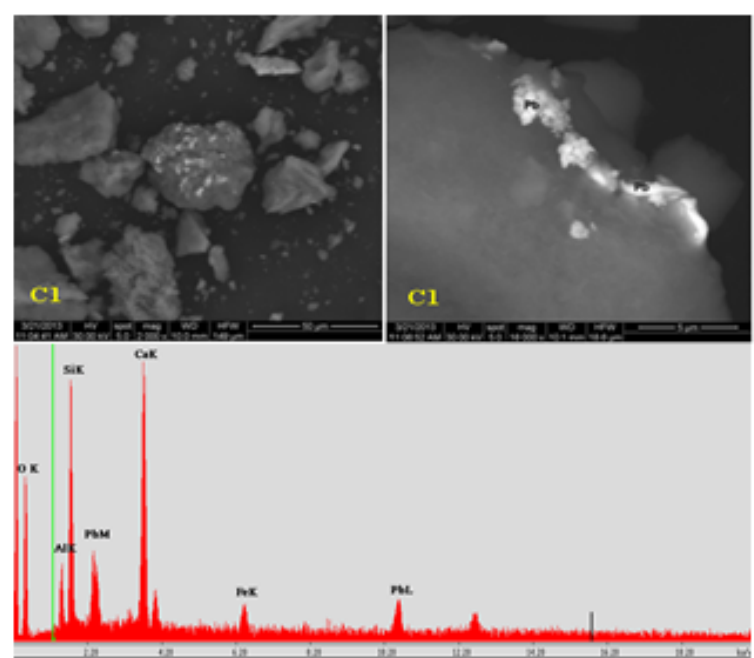

Fig 5. SEM and EDAX images for soils from Baia Mare (B3), CopsaMica (C1) and Aghires (P2)
It is also noted that the average values of the pollutants (lead) concentration are higher in Baia Mare and Copsa Mica than in the Aghires area.

\section{Conclusions}

The study presents the results of soil quality studies from three contaminated areas, affected by exploitation from Romania: northwest of Baia Mare near Romplumb S.A., Aghires quarry area Copsa Mica. The smallest values of $\mathrm{pH}$ were measured for samples from Aghires (from 3.8 to 4.2) 
followed by soils from Baia Mare ( $p H$ between 4 and 6), while in Copsa-Mica the soil is almost neutral $(\mathrm{pH}$ range between 6 and 7). The lowest values for hygroscopic water content after $3 \mathrm{~h}$ were obtained for soil from Aghires followed by the soil from the Baia Mare area.

Sieves analysis was also used for gradation and size analysis after soil drying in an oven. SEM-EDAX analysis revealed that the average values of the pollutants (lead) concentration are higher in Baia Mare and Copsa Mica than in the Aghires area. This study reports results will help to focus future research on soil remediation through new treatment methods.

\section{References}

1. CLEMENTE, R., DICKINSON, N.M., LEPP, N.W., Environmental Pollution, 155, 2008, p.254

2. GOODARZI, F., SANEI, H., GARRETT, R.G., DUNCAN, W.F., 43, 2002, p.29

3. ADRIANO, D.C., Editura Springer, New York, 2001.

4. BARMAN, S.C., SAHU, R.K., BHARGAVA, S.K., .CHATTERJEE, C., Bulletin of Environmental Contamination and Toxicology, 64, 2000, p.489

5. SINGH, S., MA, L.Q., HARRIS, W., J ournal of Environmental Quality, 30, 2001, p.1961

6. SANTAMARIA-FERNANDEZ, R., CAVE, M.R., HILL, S.J., Analytica Chimica Acta, 557, 2005, p. 344
7. NANNONI, F., PROTANO, G., RICCOBONO, F., GEODERMA, University of Siena, Italy, 2011.

8. NAVAS, A., MACHÍN, J., Applied Geochemistry, 17, 2002, p.961

9. ZHAO, L., SCHULIN, R., NOWACK, B., Environmental Science and Technology, 41, 2007, p. 2770

10. SAPLONPAI, M., SAPLONPAI, V., TRUSCA R., BALC N., Cesme, Izmir - Turkey, Conference Proceedings, 2013, p.506

11. HETTIARACHCHI, G., PIERZYNSKI, G, Environmental Programme, 23, 2004, p.78

12. LU, Y., GONG, Z.T., ZHANG, G.L., BURGHARDT, W., Geoderma, 115,2003, p. 101

13. CASTRIGNANO, A., MAZZONCINI, M., GIUGLIARINI, L., Advances in Geoecology, 31, 1998, p.105

14. CASTRIGNANO, A., GIUGLIARINI, L., RISALITI, R., MARTINELLI, N., Geoderma, 97, 2000, p.39

15. VANGRONSVELD, J., CUNNINGHAM, S.D., VANGRONS-veld J and Cunningham S D. (eds) Springer Verlag, Berlin., 1998, pp.1

16. MCGOWEN, S.L., BASTA, N.T., BROWN, G.O., J ournal of Environmental Quality, 30, 2001, p.493

17. RYAN, K., ZHANG, P., HESTERBERG, D., CHOU, J., SAYERS, D., Environmental Sciences and Technology, 35, 2001, p.3798

18. CHRYSOCHOOU, M., DERMATAS, D., GRUBB, D.G., J ournal of Hazardous Materials, 144

Manuscript received: 25.05 .2018 